\title{
KARYOTYPE OF ARION VULGARIS MOQUIN-TANDON, 1856 (GASTROPODA: PULMONATA: ARIONIDAE)
}

\author{
ALEXANDR V. GARbaR, NATALIA S. KadLUbOVSKA
}

\begin{abstract}
Ivan Franko State University, Velyka Berdichivska st., 40, Zhytomyr, 10008, Ukraine (e-mail: saguaroklub@mail.ru)
\end{abstract}

\begin{abstract}
The diploid chromosome set of Arion vulgaris Moquin-Tandon consists of 52 chromosomes, with the karyotype formula: $2 \mathrm{n}=44 \mathrm{~m}+6 \mathrm{sm}+2 \mathrm{st}=52 ; \mathrm{FN}=104$. The chromosome number $(\mathrm{n}=26,2 \mathrm{n}=52)$ of $A$. vulgaris is identical to that of $A$. subfuscus sensu lato, A. ater (L.) and A. rufus (L.) which may suggest their close relationship.
\end{abstract}

KEY WORDS: Arion vulgaris, chromosomes, karyotype

\section{INTRODUCTION}

Cytogenetic studies often provide data which are relevant to taxonomy, identification of species and to understanding of the mechanisms of speciation and evolution (BURCH 1968). However, literature data on mollusc karyotypes are scarce because of the difficulties in obtaining mitotic fields of a quality sufficient to carry out chromosome studies (PARK et al. 1999).

Most reports on mollusc chromosomes, using histological or squash techniques, dealt chiefly, or only, with chromosome numbers (for review see PATTERSON 1969, PATTERSON \& BURCH 1978). Later, the development of cytogenetic techniques, such as pre-treatment with colchicine and hypotonic treatment combined with air-drying techniques, permitted better assessment of chromosome morphology (NAKAMURA 1985, 1986). Recently developed differential staining techniques (e.g. silver-staining, Cand G-banding) started to be applied to molluscan chromosomes (THIRIOT-QUIÉVREUX 1994), as well as advanced techniques, such as the use of fluorescent in situ hybridisation (FISH) with rDNA probes to visualize the sites of the nucleolus organiser regions (NORs). Chromosome studies of gastropod molluscs have greatly increased since the reviews of PATTERSON (1969), PATTERSON \& BURCH (1978) and NAKAMURA (1986).
First descriptions of karyotypes in the family Arionidae appeared in the second half of the 20th century: BEESON (1960) investigated six species whose haploid chromosome numbers varied from $\mathrm{n}$ $=25$ to $\mathrm{n}=29$. Chromosome numbers of two slug species of the genus Arion from Ukraine were studied by GARBAR at al. (2010): A. fuscus (Draparnaud, 1805) ( $\mathrm{n}=26,2 \mathrm{n}=52)$ and A. fasciatus (Nilsson, 1823) $(n=29,2 n=58)$. In the first case the chromosome number differed from BEESON's (1960) data $(2 \mathrm{n}=50)$. The karyotype of the second species was identical to that of another closely related species A. circumscriptus Johnston, 1828 from Great Britain (BEESON 1960).

Next descriptions of arionid karyotypes were provided by PATRÃO at al. (2013) who recorded the same chromosome number for four species of Geomalacus and one species of Letourneuxia ( $\mathrm{n}=31$, $2 n=62$ ). They also found that the karyotypic formulae were different and unique to each Geomalacus species.

An invasive slug Arion vulgaris Moquin-Tandon, 1855 originates from South and Central France. At present its populations are often found in Central, Northern and Western Europe (WELTER-SCHULTES 2012). It spreads mostly anthropochorously (DE 
WiNTER 1989, VON PROSCHWITZ 1997, BRINER \& FRANK 1998). In Ukraine, the species appeared recently and quickly spread (GURAL-SVERLOVA \& GURAL 2010, GURAL-SVERLOVA 2011).

There are no literature data on the karyotype of $A$. vulgaris. Its chromosome number may prove informa- tive, since BACKELJAU \& DE BRUYN (1990) suggested that in arionids, chromosome numbers might correlate with the subgeneric division of the genus. The data can also be useful to gain insight in the recently reported hybridisation between $A$. vulgaris and $A$. rufus/A. ater (HAGNELL at al. 2003).

\section{MATERIAL AND METHODS}

The material for karyological studies was collected by the authors in the spring-autumn period of 2013. Two samples (20 specimens) from the Sakharova and Pryrodna streets in Lviv (Ukraine) were used.

Chromosome slides were prepared from gonad tissues using methods which had been successfully used to study karyotypes of other molluscs (GARBAR \& GARBAR 2007). The animals were injected with $0.02 \%$ colchicine $18 \mathrm{~h}$ before dissection. Gonad fragments were minced and subjected to hypotonic treatment for $40 \mathrm{~min}$ in distilled water. The material was fixed in a mixture of $96 \%$ ethanol and glacial acetic acid in a 3:1 ratio. Cell suspension was prepared by maceration of the material in a mixture of glacial acetic acid and $60 \%$ lactic acid (30:1); then it was dropped onto dry slides warmed to $50^{\circ} \mathrm{C}$, using a capillary pipette. The dried slides were stained for
$10 \mathrm{~min}$ in a $10 \%$ Romanovskii solution of azure-eosin in $0.01 \mathrm{M}$ phosphate buffer ( $\mathrm{pH}$ 6.8). The slides were examined in a ULAB XY-B2 microscope $(10 \times 100)$.

Metaphase plates (2n) with a satisfactory scatter of chromosomes and an equal degree of spiralisation were selected for subsequent photography and measurements. Based on the measurements, total complement length (TCL), relative length of chromosomes ( $\mathrm{Lr}$ - total length of chromosomal pair/TCL100\%) and centromeric index ( $\mathrm{Ci}$, length of short arm/chromosome length) were calculated. The morphological type of chromosomes was determined according to LEVAN's (LEVAN et al. 1964) classification. The fundamental number (FN) was determined as the number of chromosome arms in a diploid set. The linear parameters of chromosomes were processed using methods of variation statistics.

\section{RESULTS AND DISCUSSION}

The diploid set (2n) of $A$. vulgaris consists of 52 chromosomes. The TCL $=79.01 \pm 2.58 \mu \mathrm{m}$. The chromosomes gradually decrease in size from the 1 st to the 26th pair. Their relative length varies from 8.56 (1st pair) to $1.28 \%$ (26th pair) (Table 1).

The morphological characteristics of the karyotype are the following: 2nd pair - subtelocentric (st); 6th, 7th, and 8th pairs - submetacentric; remaining pairs - metacentric. The chromosomal formula is $2 \mathrm{n}=44 \mathrm{~m}+6 \mathrm{sm}+2 \mathrm{st}=52$. The fundamental number FN $=104$ (Figs 1-3).

The diploid set $(2 \mathrm{n})$ of $A$. vulgaris consists exclusively of two-arm chromosomes $(\mathrm{NF}=104)$. Such chromosomes prevail in other slugs' karyotypes

Table 1. Measurements ( $\mathrm{Ci}$ - centromeric index, $\mathrm{Lr}$ - relative length, SE - standard error) and classification of chromosomes ( $m$ - metacentric, sm - submetacentric, st - subtelocentric chromosome) of A. vulgaris

\begin{tabular}{cccccc}
\hline \multirow{2}{*}{ Pair no. } & \multicolumn{2}{c}{$\mathrm{Ci}, \%$} & \multicolumn{2}{c}{ Lr, \% } & \multirow{2}{*}{ Type } \\
\cline { 2 - 5 } & Mean & SE & Mean & SE & \\
\hline 1 & 46.73 & 0.45 & 8.56 & 0.22 & $\mathrm{~m}$ \\
2 & 23.55 & 0.77 & 6.96 & 0.11 & $\mathrm{st}$ \\
3 & 45.72 & 0.54 & 6.59 & 0.11 & $\mathrm{~m}$ \\
4 & 46.06 & 0.41 & 6.15 & 0.09 & $\mathrm{~m}$ \\
5 & 45.50 & 0.52 & 5.71 & 0.08 & $\mathrm{~m}$ \\
6 & 35.01 & 0.26 & 5.36 & 0.08 & $\mathrm{sm}$ \\
7 & 30.29 & 0.74 & 5.04 & 0.07 & $\mathrm{sm}$ \\
8 & 36.25 & 0.55 & 4.67 & 0.06 & $\mathrm{sm}$ \\
9 & 45.70 & 0.53 & 4.51 & 0.06 & $\mathrm{~m}$ \\
10 & 45.46 & 0.62 & 4.34 & 0.05 & $\mathrm{~m}$ \\
11 & 45.83 & 0.49 & 4.10 & 0.06 & $\mathrm{~m}$ \\
12 & 44.96 & 0.43 & 3.79 & 0.05 & $\mathrm{~m}$ \\
13 & 45.43 & 0.55 & 3.58 & 0.05 & $\mathrm{~m}$ \\
\hline
\end{tabular}

\begin{tabular}{cccccc}
\hline \multirow{2}{*}{ Pair no. } & \multicolumn{2}{c}{ Ci, \% } & \multicolumn{2}{c}{ Lr, \% } & \multirow{2}{*}{ Type } \\
\cline { 2 - 5 } & Mean & SE & Mean & SE & \\
\hline 14 & 46.22 & 0.49 & 3.33 & 0.04 & $\mathrm{~m}$ \\
15 & 46.79 & 0.42 & 3.11 & 0.03 & $\mathrm{~m}$ \\
16 & 45.43 & 0.45 & 2.91 & 0.03 & $\mathrm{~m}$ \\
17 & 47.26 & 0.27 & 2.69 & 0.04 & $\mathrm{~m}$ \\
18 & 47.27 & 0.44 & 2.51 & 0.05 & $\mathrm{~m}$ \\
19 & 45.95 & 0.75 & 2.38 & 0.05 & $\mathrm{~m}$ \\
20 & 48.20 & 0.40 & 2.26 & 0.04 & $\mathrm{~m}$ \\
21 & 47.71 & 0.37 & 2.08 & 0.05 & $\mathrm{~m}$ \\
22 & 46.94 & 0.55 & 1.93 & 0.05 & $\mathrm{~m}$ \\
23 & 46.59 & 0.41 & 1.78 & 0.05 & $\mathrm{~m}$ \\
24 & 47.34 & 0.51 & 1.63 & 0.05 & $\mathrm{~m}$ \\
25 & 46.24 & 0.48 & 1.47 & 0.05 & $\mathrm{~m}$ \\
26 & 46.46 & 0.46 & 1.28 & 0.05 & $\mathrm{~m}$ \\
\hline
\end{tabular}




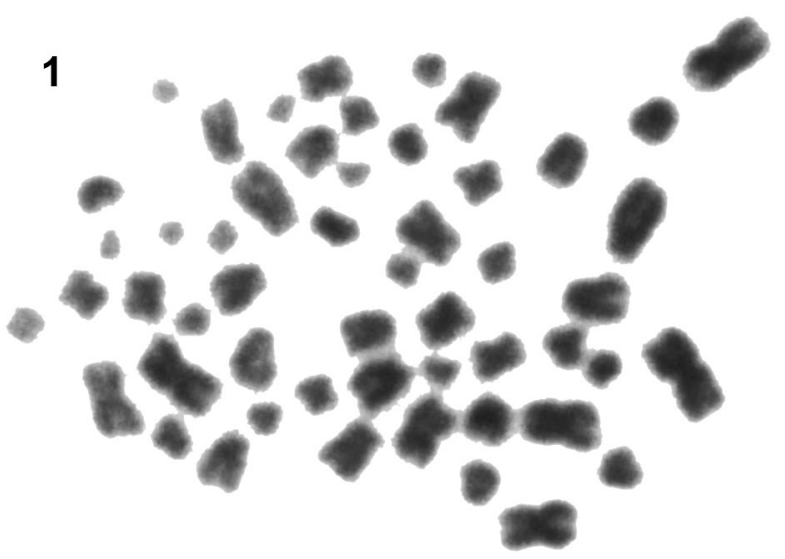

2
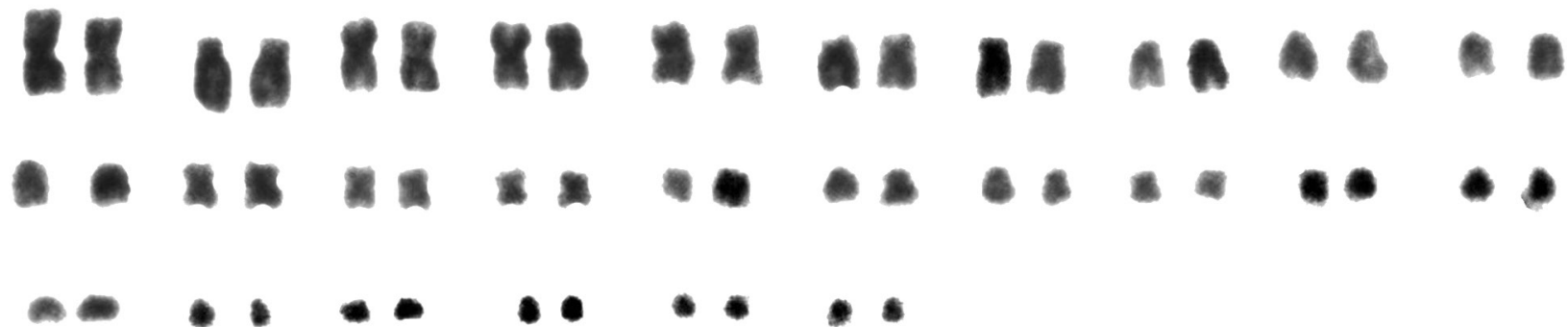

Figs 1-2. Chromosomes of A. vulgaris: 1 - mitotic metaphase (2n); 2 - karyotype. Bar represents 0.004 mm

(VITTURI 1992, VitTURI \& SPARACIO 1993, PATRÃO at al. 2013).

BEESON (1960) reported the following haploid chromosome numbers in Arion: A. ater (Linnaeus, 1758) $-\mathrm{n}=26$, A. rufus (Linnaeus, 1758) $-\mathrm{n}=26, A$. subfuscus (Draparnaud, 1805) $-\mathrm{n}=25$, A circumscriptus $-\mathrm{n}=29$, A. hortensis (Férussac, 1819) $-\mathrm{n}=28$ and $A$. intermedius (Normand, 1852) $-\mathrm{n}=28$. It was found later that the chromosome number of $A$. fus- cus (A. subfuscus sensu lato) was different ( $\mathrm{n}=26$, $2 \mathrm{n}=52)$ (GARBAR at al. 2010). Thus, the chromosome number in $A$. vulgaris $(\mathrm{n}=26,2 \mathrm{n}=52)$ is identical to that of $A$. subfuscus sensu lato, $A$. ater and $A$. rufus, which may indicate their close relationship. In this regard, hybridisation of the species is quite possible.

The previous chromosome studies on slugs (BEESON 1960) and euthyneuran gastropods in gen-

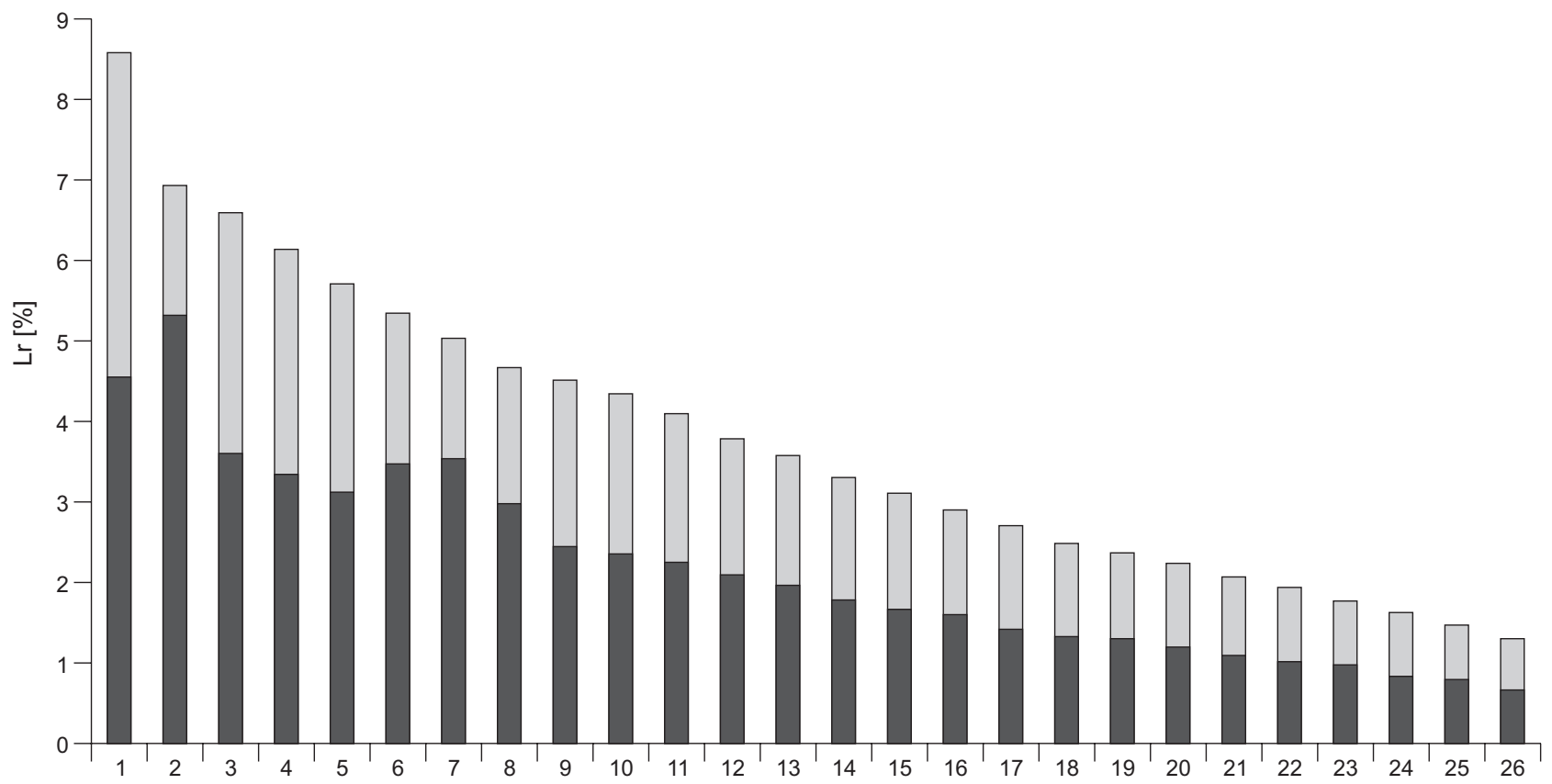

Fig. 3. Idiogram of karyotype (based on data from Table 1) 
eral (BURCH 1965) suggested that karyological data might be useful to distinguish (sub)genus level taxa in limacid and arionid slugs. There seems to be a suggestive correspondence between the haploid chromosome numbers and subgeneric groupings in the genus Arion: $\mathrm{n}=25$ in Mesarion Hesse, 1926, $\mathrm{n}=26$ in Arion Férussac, 1819, $\mathrm{n}=28$ in Kobeltia Seibert, 1873 and Microarion Hesse, 1926, and $\mathrm{n}=29$ in Carinarion

\section{CONCLUSIONS}

The diploid chromosome set of $A$. vulgaris consists of 52 chromosomes; the karyotype formula is $2 \mathrm{n}=44 \mathrm{~m}+6 \mathrm{sm}+2 \mathrm{st}=52 ; \mathrm{FN}=104)$. The chromosome number $(\mathrm{n}=26,2 \mathrm{n}=52)$ is identical with that of $A$. subfuscus sensu lato, $A$. ater and A. rufus

\section{REFERENCES}

BACKELJAU T., DE BRUYN L. 1990. On the infrageneric systematics of the genus Arion Férussac, 1819 (Mollusca, Pulmonata). Bull. Inst. Roy. Sci. Nat. Belgique, Biologie 60: 35-68.

BEESON G. 1960. Chromosome numbers of slugs. Nature 186: 257-258. http://dx.doi.org/10.1038/186257a0

BRINER T., FRANK T. 1998. The palatability of 78 wildflower strip plants to the slug Arion lusitanicus. Ann. Appl. Biol. 133: 123-133. http://dx.doi. org/10.1111/j.1744-7348.1998.tb05808.x

BURCH J. B. 1965. Chromosome numbers and systematics in Euthyneuran snails. Proc. First European Malacological Congress, London: 215-241.

BurCH J. B. 1968. Cytotaxonomy of some Japanese Semisulcospira (Streptoneura: Pleuroceridea). J. Conch. 107: 3-52.

Garbar A. V., Cyhernyshova T. N., Garbar D. A. 2010. Karyotypes of the slugs (Mollusca, Gastropoda) from the fauna of Ukraine. International Conference "Karyotaxonomy of invertebrates V", Novosibirsk: 35.

Garbar D. A., GARbar A. V. 2007. Karyological features of the genus Planorbarius (Gastropoda, Pulmonata, Bulinidae) of the Ukrainian Fauna. Cytol. Genet. 41: 4955. http://dx.doi.org/10.3103/S0095452707020089

Gural-Sverlova N. V. 2011. The invasion of Arion lusitanicus from Spain in Lviv and its possible ecological and economical aftereffects. Scientific thesis of State Nature Museum, Lviv 27: 71-80.

GuRAL-Sverlova N. V., GURAL R. I. 2010. New findings of terrestrial mollusk on the territory of Lviv and Lviv region. Scientific thesis of State Nature Museum, Lviv 26: 221-222.

Hagnell J., Schander C., Proschwitz T. vON 2003. Hybridisation in arionids: the rise of a super slug? BCPC Symposium Proc. 80: 221-226.

LEVAN A., FredGA K., SANDBERG A. 1964. Nomenclature for centromeric position on chromosomes. Hereditas
Hesse, 1926 (BEESON 1960). This observation was, among others, used to include Microarion in the subgenus Kobeltia (BACKELJAU \& DE BRUYN 1990). The identical chromosome numbers in the subgenera Mesarion and Arion ( $\mathrm{n}=26)$ may be the reason for their association. However, further karyological investigations of other Arion species are needed.

which may point to their close relationship. Since the taxonomy of this group is being currently revised, karyological data may contribute to specifying the position of some taxa.

52: 201. http://dx.doi.org/10.1111/j.1601-5223.1964. tb01953.x

NAKAMURA H. K. 1985. A review of molluscan cytogenetic information based on the CISMOCH-Computerized Index System for molluscan chromosomes. Bivalvia, Polyplacophora and Cephalopoda. Venus 44: 193-225.

NAKAMURA H. K. 1986. Chromosomes of Archaeogastropoda (Mollusca: Prosobranchia), with some remarks on their cytotaxonomy and phylogeny. Publ. Seto Mar. Biol. Lab. 31: 191-267.

PARK G. M., Kim J. J., PyUnG-RIMChUnG WANG Y., MiN D. Y. 1999. Karyotypes on three species of Chinese Mesogastropod snails, Semisulcospira libertina, S. dolichostoma and Viviparus rivularis. Korean J. Parasitol. 37: 5-11. http://dx.doi.org/10.3347/kjp.1999.37.1.5

PATRÃo C., SOUSA J. T. DE, JORDAENS K., BACKELJAU T., CASTIlHO R., LeITÃo A. 2013. Geomalacus and Letourneuxia (Mollusca, Pulmonata): a cytogenetic assessment. Malacologia 56: 333-338. http://dx.doi. org/10.4002/040.056.0222

PATtERSON C. M. 1969. Chromosomes of molluscs. Proc. 2nd Symposium of Mollusca, Vol. 2. Ernakulam, Colchin (India), Marine Biological Association, Bangalore, India: 635-689.

PATterson C. M., BurCH J. B. 1978. Chromosomes of pulmonate molluscs. In: FretTer V., PEAKe J. (eds). Pulmonates. Vol. 2a. Systematics, evolution and ecology. Academic Press, New York, London, pp. 171-217.

PROSCHWITZ T. VON 1997. Der Aufbau einer nationalen Computer-Datenbank für landlebende Mollusken im Naturhistorischen Museum Goteborg, Schweden. Mitt. dtsch. Malakozool. Gesell. 60: 27-33.

ThIRIOT-QuievreuX C. 2003. Advances in chromosomal studies of gastropod molluscs. J. Mollus. Stud. 69: 187-201. http://dx.doi.org/10.1093/mollus/69.3.187

VITTURI R. 1992. Conventionally stained chromosomes constitutive heterochromatin and nucleolus organiz- 
er regions in Milax nigricans (Gastropoda, Pulmonata). Chromatin 1: 147-155.

VITTURI R., SPARACIO I. 1993. Spermatocyte chromosome analysis of the Lehmannia melitensis (Lessona and Pollonera, 1891) (Mollusca, Pulmonata) using conventional, NOR- and C- banding techniques. Caryologia 46: 189-199. http://dx.doi.org/10.1080/00087114.19 93.10797259
WELTER-SCHULTES F. 2012. European non-marine molluscs, a guide for species identification. Planet Poster Edition, Göttingen.

WinTER A. J. DE 1989. Arion lusitanicus Mabille in Nederland (Gastropoda, Pulmonata, Arionidae). Basteria 53: 4951.

Received: April 4th/16th, 2014

Revised: September 15th, 2014

Accepted: September 18th, 2014

Published on-line: November 14th, 2014 